\title{
Trichogramma pretiosum attraction due to the Elasmopalpus lignosellus damage in maize
}

\author{
Luciane Modenez Saldivar Xavier(1), Raúl Alberto Laumannn(2), Miguel Borges(2), Diego Martins Magalhães(2), \\ Evaldo Ferreira Vilela ${ }^{(1)}$ and Maria Carolina Blassioli-Moraes ${ }^{(2)}$
}

\begin{abstract}
(1)Universidade Federal de Viçosa, Departamento de Biologia Animal, Avenida P.H. Rolfs, s/non, Campus Universitário, CEP 36571-0000 Viçosa, MG, Brazil. E-mail: luciane.ufv@gmail.com, evaldovilela@gmail.com ${ }^{(2)}$ Embrapa Recursos Genéticos e Biotecnologia, Núcleo Temático Controle Biológico, Caixa Postal 02372, CEP 70849-970 Brasília, DF, Brazil. E-mail: laumann@cenargen.embrapa.br, mborges@cenargen. embrapa.br, diego.mm@limao.com.br, mcbmorae@cenargen.embrapa.br
\end{abstract}

Abstract - The objective of this work was to evaluate if corn plants damaged by the lesser cornstalk borer (Elasmopalpus lignosellus) larvae release volatile organic compounds capable of attracting the egg parasitoid Trichogramma pretiosum. The treatments consisted of plants subjected to harm caused by E. lignosellus larvae, plants subjected to mechanical damage, and undamaged plants. The parasitoid was more attracted by the volatiles released by the insect damaged plants than to those released by undamaged corn plants, after 24 and 72 hours. The volatiles ( $Z$ )-3-hexenyl acetate, $\beta$-pinene, $\beta$-myrcene, $(E)$-4,8-dimethylnona-1,3,7-triene, and benzothiazole were released in significantly larger quantities by damaged plants. Volatiles released by corn plants damaged by E. lignosellus larvae may act as an indirect defense, attracting by $T$. pretiosum.

Index terms: egg parasitoid, tritrophic interaction, semiochemicals, volatile organic compounds.

\section{Atração de Trichogramma pretiosum devida ao dano causado por Elasmopalpus lignosellus em milho}

Resumo - O objetivo deste trabalho foi avaliar se plantas de milho danificadas por lagartas da broca-do-colo (Elasmopalpus lignosellus) liberam compostos orgânicos voláteis capazes de atrair o parasitoide de ovos Trichogramma pretiosum. Os tratamentos consistiram de plantas submetidas a dano por lagartas de E. lignosellus, plantas submetidas a dano mecânico e plantas sem danos. O parasitoide foi mais atraído pelos voláteis emitidos por plantas danificadas pela lagarta do que pelos liberados pelas plantas sem danos, após 24 e 72 horas. Os volatéis (Z)-3-acetato de hexenila, $\beta$-pineno, $\beta$-mirceno, $(E)$-4,8-dimetilnona-1,3,7-trieno e benzotiazol foram liberados em quantidades significativamente maiores pelas plantas danificadas. Os voláteis liberados pelas plantas de milho danificadas por lagartas de E. lignosellus podem agir como defesa indireta, por meio da atração a T. pretiosum.

Termos para indexação: parasitoide de ovos, interação tritrófica, semioquímicos, compostos orgânicos voláteis.

\section{Introduction}

The lesser cornstalk borer (LCB) [Elasmopalpus lignosellus (Zeller, 1848) (Lepidoptera, Pyralidae)] is a major corn pest in North, Central, and South America, and has been reported to attack at least 60 different plant species (Stone, 1968).

Since the early 1980s, efforts have been directed to develop new alternatives based on semiochemicals and natural enemies to control E. lignosellus (Lynch et al., 1984; Pires et al., 1992; Jham et al., 2005, 2007). However, in Brazil, the currently used method is still based on pesticides. Therefore, studies on the chemical communication between LCB and host plants could provide information to develop innovative tools involving plant semiochemicals to monitor or control this major pest.

Parasitoids and predators are capable to distinguish complex mixtures of plant odors that indicate the presence or absence of potential hosts/preys (Vet \& Dicke, 1992; Hilker \& Meiners, 2002; Heil, 2008). Consequently, plant volatiles could be used as an alternative in integrated pest control (Vet \& Dicke, 1992; Moraes et al., 2005, 2008, 2009; Michereff et al., 2011), attracting and retaining natural enemies in crops, thus improving their efficiency. Herbivory induced plant volatiles (HIPVs) have been reported in a wide range of tritrophic systems, in different crops, such

Pesq. agropec. bras., Brasília, v.46, n.6, p.578-585, jun. 2011 
as lima beans, broad beans, cultivated tobacco, and soybean (Colazza et al., 2004a, 2004b; Moraes et al., 2005, 2008; Heil \& Ton, 2008). The use of HIPVs to control beneficial insects has been proposed in different systems and is highly indicated to control pests and natural enemies, since these volatiles are naturally released and present at low or non-toxic levels (Vet \& Dicke, 1992; Colazza et al., 2004a, 2004b; Moraes et al., 2005, 2008; Heil, 2008; Heil \& Ton, 2008). However, there are still few known practical studies on the application of plant semiochemicals (Köllner et al., 2008; Williams III et al., 2008).

The objective of this work was to evaluate if corn plants damaged by E. lignosellus larvae release volatile organic compounds capable of attracting the egg parasitoid Trichogramma pretiosum Riley, 1879 (Hymenoptera: Trichogrammatidae).

\section{Materials and Methods}

Corn seeds [Zea mays (L.)] var. BR-106, obtained from Embrapa Milho e Sorgo, located in Sete Lagoas, $\mathrm{MG}$, Brazil, were germinated in containers filled with sterilized soil, and kept in a growth chamber at $26 \pm 1^{\circ} \mathrm{C}$ and $80 \%$ relative humidity $(\mathrm{RH})$. Plants with two completely expanded leaves (17 to $22 \mathrm{~cm}$ long) were used in the experiment.

Elasmopalpus lignosellus populations were kept under laboratory conditions at Embrapa Recursos Genéticos e Biotecnologia, in Brasília, DF, Brazil $\left(15^{\circ} 47^{\prime} \mathrm{S}, 47^{\circ} 55^{\prime} \mathrm{W}\right)$. The population was first collected in sugarcane fields in Viçosa, $\mathrm{MG}$, Brazil $\left(20^{\circ} 45^{\prime} \mathrm{S}\right.$, $\left.42^{\circ} 52^{\prime} \mathrm{W}\right)$. The larvae were fed with an artificial diet (Chalfant, 1975; Viana, 1993) and kept in rearing chambers at $28 \pm 0.5^{\circ} \mathrm{C}$ and $20 \pm 10 \% \mathrm{RH}$, with a photophase of 12 hours.

Trichogramma pretiosum colony was started from insects collected from a mass rearing colony at Embrapa Arroz e Feijão, in Santo Antônio de Goiás, GO, Brazil. The parasitoids were kept at Embrapa Recursos Genéticos e Biotecnologia in acrylic containers $(7.5 \times 1.3 \mathrm{~cm})$ and fed with drops of honey twice a week. Colonies of $T$. pretiosum were kept under a photophase of 14 hours, at $26.0 \pm 2.0^{\circ} \mathrm{C}$ and $65 \pm 10 \%$ RH. The parasitoids were mass reared, and Anticarsia gemmatalis eggs were offered as hosts to females for 24 hours. The parasitized eggs were transferred to acrylic recipients $(7.5 \times 1.3 \mathrm{~cm})$ and kept in the same conditions until the full development of the parasitoids.
Naïve females (24-48 hours in adult stage) were used in the bioassays.

Three treatments were used to evaluate if E. lignosellus feeding damage induces the indirect defense of corn plants by attracting $T$. pretiosum: corn plants infested with E. lignosellus larvae (third instar), manually damaged (mechanically damaged) corn plants, and undamaged corn plants. Mechanical damage was done with a syringe needle (BD precision glide $1.20 \times 40 \mathrm{~mm} 18 \mathrm{G} 1$ ) by making a $1 \mathrm{~cm}$ cut along the leaf and by puncturing a 1-cm-deep hole at the base of the stem.

Corn plants from different treatments were individually placed within cylindrical 10 -L glass chambers. The top of the pot was covered with aluminum foil to reduce contamination from soil volatiles. A glass tube containing a Super Q adsorbent filter with $100 \mathrm{mg}$, and 80-100 mesh, (Alltech, State College, PA, USA) was connected with a polytetrafluoroethylene (PTFE) tube to a vacuum pump at a flow rate of $600 \mathrm{~mL}$ per min, and the air entrance was connected to a charcoal-filtered air flow $(1,000 \mathrm{~mL}$ per min), creating a positive push-pull system. Plant volatiles were collected during four consecutive days, and a sample was taken every 24 hours.

Volatiles from manually damaged plants were collected during the first 24 hours after injury, since the induction of volatiles by mechanical damage occurs at the moment of injury (Loughrin et al., 1994).

Volatiles were eluted from the Super Q adsorbent with $500 \mu \mathrm{L}$ of n-hexane, pre-concentrated to $100 \mu \mathrm{L}$ under a $\mathrm{N}_{2}$ flow. Extracts were stored in a glass vial at $-20^{\circ} \mathrm{C}$ until needed.

Quantitative analysis was carried out in a Shimadzu 17A gas chromatograph (Shimadzu, Kyoto, Japan) with a flame ionization detector and a DB-5 column (30 m x $0.25 \mathrm{~mm}$ ID, $0.25 \mu \mathrm{m}$ film) maintained at $50^{\circ} \mathrm{C}$ for $2 \mathrm{~min}$, and then programmed at $5^{\circ} \mathrm{C}$ per min to $180^{\circ} \mathrm{C}$, and $10^{\circ} \mathrm{C}$ per min until $250^{\circ} \mathrm{C}(20 \mathrm{~min})$, using helium as a carrier gas. The compounds were quantified using 16-hexadecanolide as an internal standard (final concentration of $19.6 \mu \mathrm{g} \mathrm{mL}^{-1}$ ). The qualitative composition of the chosen extracts was analyzed using a QP-2010 Shimadzu quadruple mass spectrometer (Shimadzu, Kyoto, Japan) equipped with a DB-5 capillary column ( $30 \mathrm{~m} \times 0.32 \mathrm{~mm}$ ID, $0.25 \mu \mathrm{m}$ film) and a splitless injector. The oven temperature was programmed at $50^{\circ} \mathrm{C}$ for $2 \mathrm{~min}$, and then increased at $5^{\circ} \mathrm{C}$ per min to $150^{\circ} \mathrm{C}$, and $10^{\circ} \mathrm{C}$ per min until $250^{\circ} \mathrm{C}$ 
(kept for $30 \mathrm{~min})$. Electron impact ionization $(70 \mathrm{eV}$, source temperature $200^{\circ} \mathrm{C}$ ) was used in the sample analysis. The compounds were identified by comparing spectra with library databases (NIST), and subsequent confirmation was done using authentic standards. Cyclosativene and (E)- $\alpha$-bergamotene compounds were identified by comparison to the database and to Kováts index, since authentic standards were not available.

Linalool was co-eluted with hydrocarbon undecane and quantified by single ion monitoring in a GC-MS Shimadzu QP2010 (Shimadzu, Kyoto, Japan) equipped with a quadrupole analyzer, a nonpolar DB-5 column with $30 \mathrm{~m} \times 0.25 \mu \mathrm{m}$ film, (J\&W Scientific, Folsom, $\mathrm{CA}$, USA), and a splitless injector $\left(250^{\circ} \mathrm{C}\right)$; helium was used as the carrier gas. Electron impact ionization $\left(70 \mathrm{eV}\right.$, source temperature $200^{\circ} \mathrm{C}$ ) was also used in the sample analysis. Three samples selected from each treatment were injected in triplicate when monitoring the ions $\mathrm{m} / \mathrm{z}$ 93, 136, and 154. Calibration curves (replicates) were built using five concentration levels of linalool $\left(6.25,12.5,25.0,50.0\right.$, and $\left.125.0 \mathrm{ng} \mu \mathrm{L}^{-1}\right)$.

The chemical analysis of the volatiles from plants damaged by larvae during the four sampled days showed larger quantities of volatile compound production. However, this response was observed only 24 and 72 hours after plants were damaged. In order to evaluate if the larvae fed continuously, 40 corn plants were infested with E. lignosellus larvae. Corn seeds were germinated in conical plastic containers $(2.5 \times 12.5 \mathrm{~cm})$ filled with sterilized soil in a growth chamber $\left(26 \pm 1^{\circ} \mathrm{C}\right.$ with $\left.80 \% \mathrm{RH}\right)$. When the plants reached 17 to $22 \mathrm{~cm}$ of height and had two complete expanded leaves (17 days after germination), they were individualized in acrylic Petri dishes $(15 \mathrm{x} 1 \mathrm{~cm})$ for the bioassays. Third instar larvae of E. lignosellus were, then, placed in the Petri dishes in order to observe its feeding behavior. The larvae were kept without food for 24 hours, to maintain similar conditions to those of the previous experiments. Food consumption was assessed during four consecutive days, and the parts of the leaves consumed by the larvae were analyzed.

Bioassays were performed to evaluate if changes on the volatile profile of corn subjected to different treatments can modify the foraging behavior of the egg parasitoid T. pretiosum. Plants with one third instar larvae of E. lignosellus were placed inside transparent micropore plastic bags and the larvae were allowed to feed for $24,48,72$ or 96 hours before the plants were used in the bioassays. Undamaged and manually damaged plants were kept in the same conditions, but in different rooms to avoid chemical signalling.

In order to evaluate the attractiveness of the volatiles to T. pretiosum, an acrylic block with a Y-shaped cavity $(19 \mathrm{x} 19 \mathrm{~cm})$ and a $1 \mathrm{~cm}$ thickness sandwiched between two glass plates was used as a bioassay arena (Moraes et al., 2005). Larva damaged plants and undamaged plants were placed in glass chambers connected with silicon tubes to the olfactometer arms. Filtered (with activated charcoal) and humidified air was forced through the system at $600 \mathrm{~mL}$ per min at the entrance and $200 \mathrm{~mL}$ per min at the exit, in a push-pull system. The olfactometer was illuminated from above by two 40 W fluorescent lamps, (Sylvania, São Paulo, SP, Brazil). A single $T$. pretiosum female was introduced at the base of the Y-tube and observed for $10 \mathrm{~min}$. First choice was considered when the insect entered one of the olfactometer arms and remained there for at least $20 \mathrm{~s}$. Each parasitoid was used once, and the plant was used in five bioassays and then replaced with another one. The position of the olfactometer was changed for each bioassay to avoid any bias in the parasitoid response. The following bioassays were carried out: $T$. pretiosum response to undamaged corn plant vs. filtered and humidified air $(n=60)$, T. pretiosum response to manually damaged corn plant vs. undamaged corn plant $(\mathrm{n}=60)$, and $T$. pretiosum response to larvae damaged corn plant vs. undamaged corn plant $(n=60)$. The first two bioassays used plants 24 hours after treatment, while the other bioassays were carried out with plants $24,48,72$, and 96 hours after treatment.

The analyses were done using $\mathrm{R}$ software ( $\mathrm{R}$ Development Core Team, 2010). The total amount of volatiles and individual compounds in each treatment were analyzed using the generalized linear model (GLM) with Gamma distribution. The choices made by the parasitoid in the Y-tube bioassays were analyzed by logistic regression (logit of the proportion of response to each treatment) and by the estimation of the probability of choosing a test odor. The fitted model used a factor for each side (left or right) on which the test odor was presented in order to control this variability. The hypothesis of no preference $(50 \%$ for the first decision to each odor) was assessed by the chi-square test $\left(\chi^{2}\right)$. 


\section{Results and Discussion}

The total amount of volatiles released did not differ significantly between damaged and undamaged plants (Figure 1). The chemical profile analysis of the extracts obtained from corn plants subjected to each of the three treatments also did not show qualitative differences in the compounds identified by GC-MS (Figure 2, Table 1). However, significant differences were observed in the quantitative analysis when the compounds were evaluated individually. The GLM

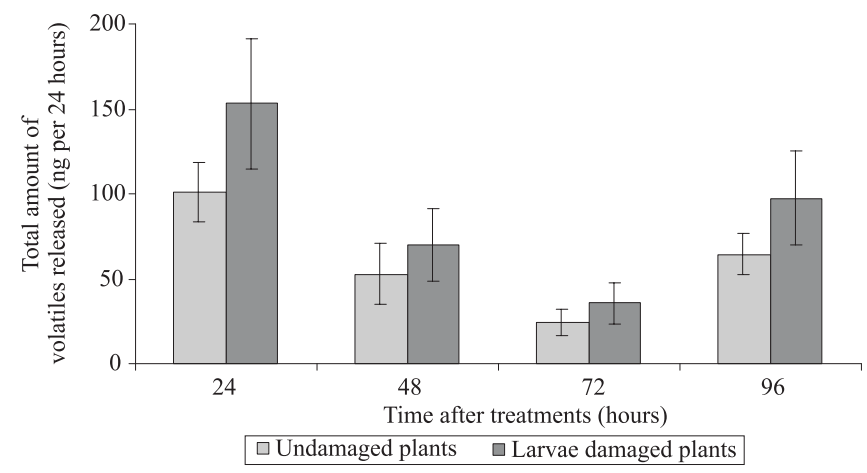

Figure 1. Total amount of volatiles (mean \pm SE) obtained from corn plants subjected to two treatments during four days: corn plants damaged by Elasmopalpus lignosellus larvae and undamaged plants. The effect of the treatment was not significant by the GLM with Gamma distribution. showed that the green leaf volatile (Z)-3-hexenyl acetate, the terpenes $\beta$-pinene and $\beta$-myrcene, and the (E)-4,8-dimethylnona-1,3,7-triene (DMNT), and benzothiazole were released in greater amounts by plants damaged by larvae than by undamaged plants. $\beta$-myrcene was released in larger quantities $(p=0.05)$ at 72 hours after the treatment, while DMNT was produced in greater amounts at 24 hours $(\mathrm{p}=0.01), 48$ hours $(\mathrm{p}=0.03)$, and 96 hours $(\mathrm{p}=0.02)$. $(Z)-3$-hexenyl acetate was released in larger quantities at 24 hours $(p=0.03)$ and 96 hours $(\mathrm{p}=0.03)$ after the treatment, whereas $\beta$-pinene was released in greater amounts after 24 hours $(p=0.02)$ and benzothiazole after 72 hours $(p=0.05)$ (Figure 3, Table 1).

Only four larvae $(10 \%)$ of the total $(n=40)$ fed consecutively during the four days of evaluation; $57 \%$ of the other larvae fed on the first day, $39 \%$ on the second day, $83 \%$ on the third day, and $53 \%$ on the fourth day, which indicates that, in general, larvae feed with fasting intervals of 24 to 72 hours.

In the Y-tube olfactometer bioassays, $T$. pretiosum did not show preference for odors from manually damaged plants in comparison to undamaged plants or to undamaged plants contrasted to air (Figure 4A). The egg parasitoid showed preference for odors from plants damaged by larvae in comparison to undamaged plants after 24 hours $(p=0.04)$ and 72 hours $(p=0.04)$

Table 1. Mean \pm SE amounts (ng per 24 hours) of volatiles collected from undamaged and larvae damaged corn plants after $24,48,72$, and from manually damaged plants after 24 hours.

\begin{tabular}{|c|c|c|c|c|c|c|c|c|c|c|}
\hline \multirow[t]{2}{*}{ Compounds } & \multirow[t]{2}{*}{$\mathrm{KI}$} & \multicolumn{4}{|c|}{ Undamaged plants } & \multirow{2}{*}{$\begin{array}{c}\text { Manually damaged } \\
\text { plants }\end{array}$} & \multicolumn{4}{|c|}{ Plants damaged by Elasmopalpus lignosellus larvae } \\
\hline & & 24 hours & 48 hours & 72 hours & 96 hours & & 24 hours & 48 hours & 72 hours & 96 hours \\
\hline$\alpha$-pinene & 938 & $1.56 \pm 0.40$ & $1.48 \pm 1.20$ & $1.90 \pm 1.43$ & $3.77 \pm 1.88$ & $1.45 \pm 0.21$ & $7.46 \pm 4.77$ & $2.37 \pm 1.12$ & $1.46 \pm 0.61$ & $6.27 \pm 2.35$ \\
\hline Camphene & 958 & $3.55 \pm 1.27$ & $1.49 \pm 1.24$ & $0.83 \pm 0.38$ & $1.65 \pm 1.02$ & $1.21 \pm 0.13$ & $1.51 \pm 0.48$ & $1.06 \pm 0.30$ & $3.16 \pm 2.73$ & $4.50 \pm 2.24$ \\
\hline$\beta$-pinene & 983 & $0.64 \pm 0.18$ & $0.64 \pm 0.37$ & $0.33 \pm 0.21$ & $0.79 \pm 0.32$ & $4.31 \pm 1.18$ & $3.18 \pm 1.53$ & $2.50 \pm 1.62$ & $1.56 \pm 1.19$ & $3.95 \pm 2.08$ \\
\hline 6-methyl-5-heptene-2-one & 989 & $8.22 \pm 3.10$ & $1.34 \pm 0.46$ & $1.59 \pm 0.73$ & $3.83 \pm 1.37$ & $21.70 \pm 6.56$ & $8.27 \pm 2.69$ & $4.83 \pm 2.24$ & $0.80 \pm 0.38$ & $6.44 \pm 3.72$ \\
\hline$\beta$-myrcene & 993 & $1.27 \pm 0.28$ & $1.18 \pm 0.43$ & $0.27 \pm 0.08$ & $2.64 \pm 1.61$ & $7.89 \pm 3.77$ & $1.44 \pm 0.52$ & $2.81 \pm 1.85$ & $1.87 \pm 1.25$ & $9.76 \pm 5.43$ \\
\hline (Z)-3-hexenyl acetate & 1,008 & $3.64 \pm 1.05$ & $0.75 \pm 0.37$ & $0.28 \pm 0.15$ & $1.48 \pm 0.47$ & $1.80 \pm 0.82$ & $11.71 \pm 3.57$ & $7.92 \pm 5.23$ & $2.36 \pm 1.29$ & $4.88 \pm 1.29$ \\
\hline Limonene & 1,036 & $24.90 \pm 6.35$ & $10.25 \pm 2.86$ & $3.22 \pm 0.93$ & $15.90 \pm 5.69$ & $1.12 \pm 0.44$ & $25.43 \pm 8.65$ & $11.33 \pm 3.07$ & $6.09 \pm 1.95$ & $13.38 \pm 4.21$ \\
\hline Linalool & 1,102 & $0.61 \pm 0.47$ & $4.05 \pm 1.68$ & $2.75 \pm 2.33$ & $0.21 \pm 0.25$ & - & $4.72 \pm 1.26$ & $3.86 \pm 1.82$ & $2.07 \pm 0.26$ & $4.88 \pm 1.80$ \\
\hline $\mathrm{DMNT}^{(1)}$ & 1,119 & $2.43 \pm 0.85$ & $0.15 \pm 0.04$ & $0.17 \pm 0.05$ & $1.96 \pm 0.74$ & $4.30 \pm 1.56$ & $17.21 \pm 5.20$ & $0.64 \pm 0.20$ & $0.62 \pm 0.36$ & $13.82 \pm 4.07$ \\
\hline Benzothiazole & 1,200 & $5.70 \pm 0.92$ & $2.33 \pm 0.87$ & $0.68 \pm 0.15$ & $2.73 \pm 0.60$ & $4.70 \pm 2.71$ & $8.35 \pm 4.12$ & $7.63 \pm 3.25$ & $2.60 \pm 1.47$ & $4.83 \pm 1.52$ \\
\hline Cyclosativene* & 1,227 & $1.15 \pm 0.41$ & $1.60 \pm 0.53$ & $3.20 \pm 2.05$ & $1.97 \pm 0.82$ & $3.37 \pm 1.13$ & $3.52 \pm 1.17$ & $1.75 \pm 0.20$ & $0.46 \pm 0.07$ & $3.07 \pm 1.45$ \\
\hline Unknown sesquiterpenoid & 1,373 & $7.32 \pm 1.70$ & $0.93 \pm 0.63$ & $0.88 \pm 0.32$ & $3.98 \pm 1.12$ & $15.52 \pm 5.47$ & $8.32 \pm 3.24$ & $1.21 \pm 0.23$ & $0.51 \pm 0.07$ & $3.20 \pm 0.98$ \\
\hline Unknown sesquiterpenoid & 1,377 & $6.72 \pm 1.42$ & $1.51 \pm 0.73$ & $1.99 \pm 0.53$ & $3.29 \pm 0.78$ & $15.52 \pm 2.67$ & $5.73 \pm 1.26$ & $7.54 \pm 4.01$ & $4.40 \pm 3.75$ & $5.97 \pm 2.19$ \\
\hline (E)- $\beta$-caryophyllene & 1,425 & $3.20 \pm 0.98$ & $1.41 \pm 0.97$ & $0.88 \pm 0.26$ & $1.73 \pm 0.65$ & $3.41 \pm 1.04$ & $5.21 \pm 2.15$ & $0.55 \pm 0.23$ & $1.76 \pm 1.31$ & $1.77 \pm 0.54$ \\
\hline$(E)$ - $\alpha$-bergamotene* & 1,456 & $5.84 \pm 2.19$ & $4.78 \pm 2.08$ & $1.23 \pm 0.51$ & $5.51 \pm 2.36$ & $32.48 \pm 11.46$ & $13.09 \pm 4.21$ & $2.33 \pm 0.72$ & $2.10 \pm 1.05$ & $3.62 \pm 1.64$ \\
\hline Geranyl acetone & 1,459 & $1.01 \pm 0.62$ & $2.43 \pm 1.42$ & $1.61 \pm 1.19$ & $1.18 \pm 0.56$ & $1.74 \pm 0.78$ & $1.81 \pm 1.27$ & $1.60 \pm 0.95$ & $0.41 \pm 0.25$ & $1.87 \pm 1.28$ \\
\hline (E)- $\beta$-farnesene & 1,460 & $12.57 \pm 2.32$ & $7.37 \pm 3.14$ & $3.70 \pm 0.91$ & $6.96 \pm 1.33$ & $34.54 \pm 6.13$ & $18.54 \pm 5.80$ & $9.29 \pm 2.00$ & $3.33 \pm 0.92$ & $5.52 \pm 1.25$ \\
\hline $\mathrm{TMTT}^{(2)}$ & 1,584 & $1.56 \pm 0.40$ & $13.12 \pm 8.91$ & $1.70 \pm 0.73$ & $4.97 \pm 2.46$ & $3.47 \pm 1.30$ & $12.20 \pm 7.38$ & $4.32 \pm 1.31$ & $1.98 \pm 0.68$ & $4.63 \pm 1.55$ \\
\hline
\end{tabular}

${ }^{(1)}(E)$-4,8-dimethylnona-1,3,7-triene. ${ }^{(2)}(E, E)-4,8,12$-trimethyltrideca-1,3,7,11-tetraene. *Tentatively identified compound. 
(Figure 4B), indicating that $T$. pretiosum can recognize volatiles emitted by plants damaged by larvae.

DMNT production was induced in corn plants at 24, 48, and 96 hours after the larvae started to cause damage; however, the egg parasitoid only responded 24 and 72 hours after the treatment, which indicates that this compound alone is probably not responsible for the attraction of T. pretiosum. The same pattern was observed for (Z)-3-hexenyl acetate and benzothiazole. Therefore, $T$. pretiosum should probably use a blend of compounds emitted by larvae damaged corn plants to find hosts. However, $\beta$-myrcene could be a key compound, since it was the only one induced in plants damaged by larvae 72 hours after being damaged and the egg parasitoid responded to these plants.

In the feeding behavior experiment, the larger number of feeding insects was observed at 24 and 72 hours. Since third instar larvae do not feed continuously, the plant defense system is probably activated when the larvae inject saliva into the plant, i.e., the induction of plant defense occurs during feeding. These results indicate that if there is an inductor present in larvae saliva, its effect does not last more than 24 hours.

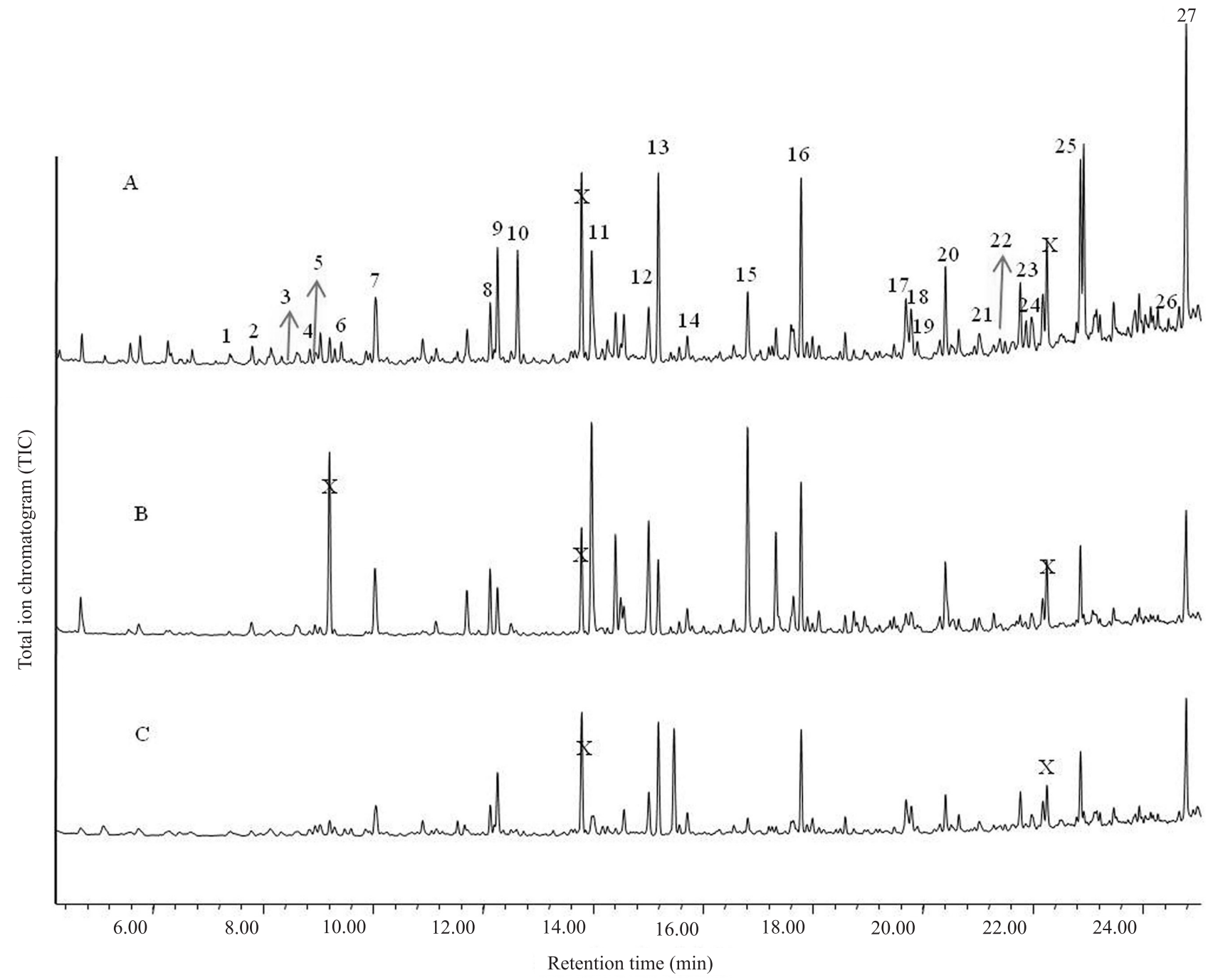

Figure 2. Chromatogram profile of the volatiles released by corn. A, corn plants damaged by Elasmopalpus lignosellus larvae; B, undamaged plants; $\mathrm{C}$, manually damaged plants. 1, $\alpha$-pinene; 2 , camphene; 3, $\beta$-pinene; 4, 6-methyl-5-heptene-2-one; 5, $\beta$-myrcene; 6 , ( $Z$ )-3-hexenyl acetate; 7, limonene; 8, linalool and undecane (co-eluting); 9, nonanal; 10, (E)-4,8-dimethylnona-1,3,7-triene; 11, 3-ethyl benzaldehyde; 12, dodecane; 13, decanal; 14, benzothiazole; 15, p-ethyl-acetophenone; 16, tridecane; 17, cyclosativene; 18, unknown sesquiterpenoid; 19 , unknown sesquiterpenoid; 20, tetradecane; $21,(E)$ - $\beta$-caryophyllene; 22, $\beta$-bergamotene; 23 , geranyl acetone; $24,(E)$ - $\beta$-farnesene; 25 , pentadecane; 26, $(E, E)$-4,8,12-trimethyltrideca-1,3,7,11-tetraene; 27, hexadecane and X contaminant (isophthalate and derivatives). 
A detailed understanding of the biosynthesis and timing of volatile organic compound releases is necessary to use HIPV as a novel tool in crop protection and to understand the perception and exploitation mechanisms of these chemical signals through their natural enemies (D'Alessandro \& Turlings, 2006). Determining the relative importance of individual compounds or groups of compounds for a specific parasitoid is possibly one of the major and most difficult questions that need to be answered to better understand the role of each compound in the attraction of the egg parasitoid (D’Alessandro \& Turlings, 2006; D'Alessandro et al., 2009).
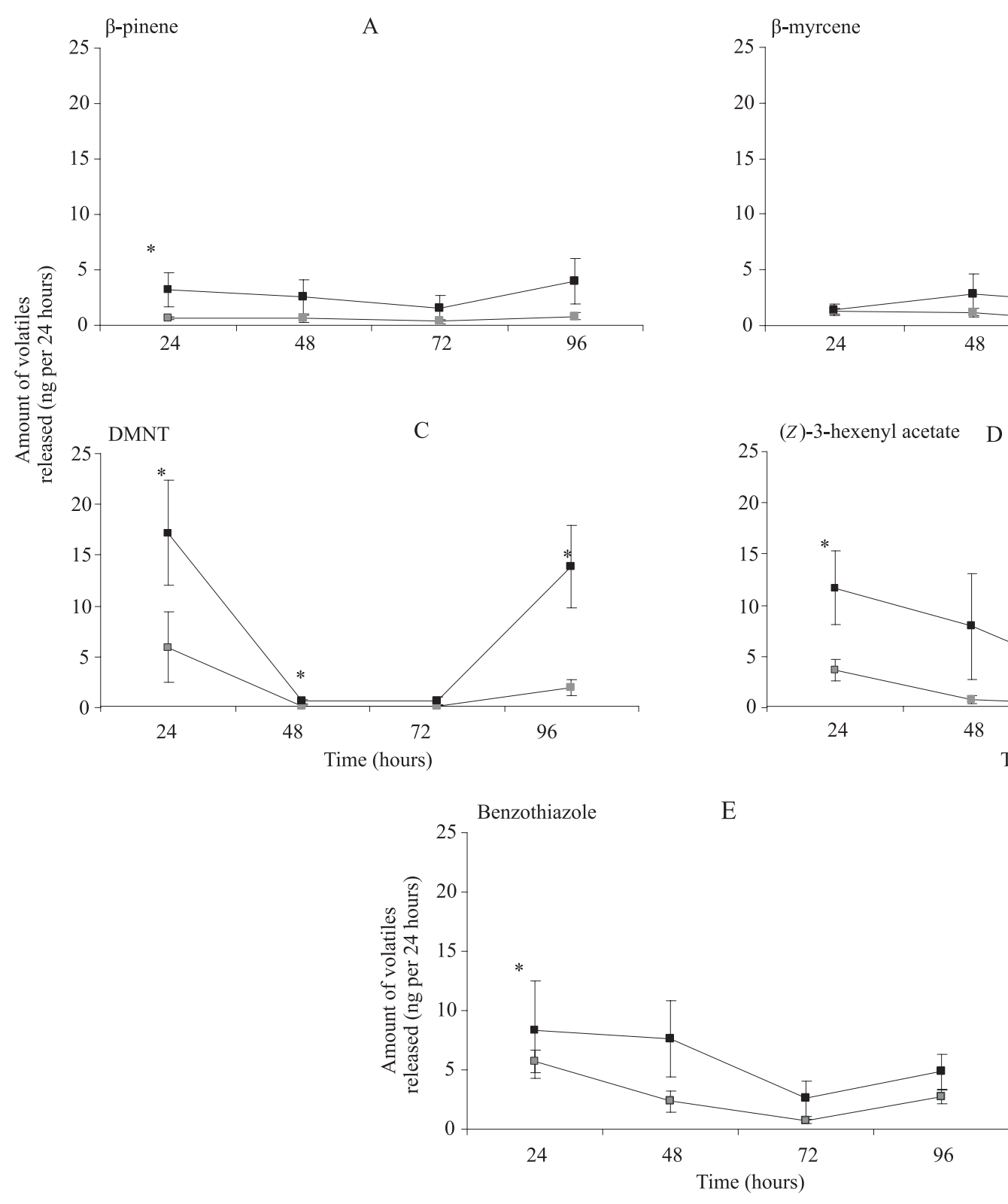

$\multimap-$ Undamaged plants $\longrightarrow$ - Larvae damaged plants

Figure 3. The amount (ng per 24 hours) of five main volatile compounds released during four days, responsible for the difference between corn plants damaged by Elasmopalpus lignosellus and undamaged corn plants. A, $\beta$-pinene; B, $\beta$-myrcene; C, (E)-4,8-dimethylnona-1,3,7-triene (DMNT); D, (Z)-3-hexenyl acetate; E, benzothiazole. *Significant at 5\% probability by the chi-square test. 
A
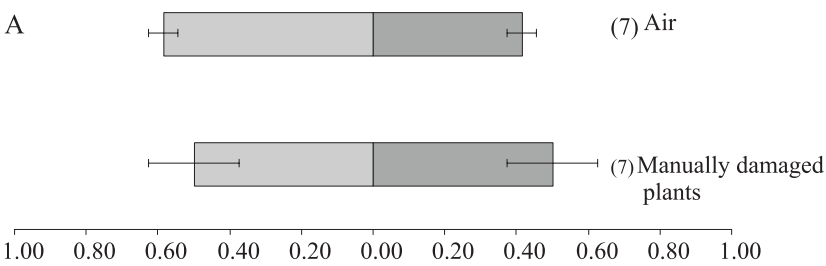

Undamaged plants

$\mathrm{B}$

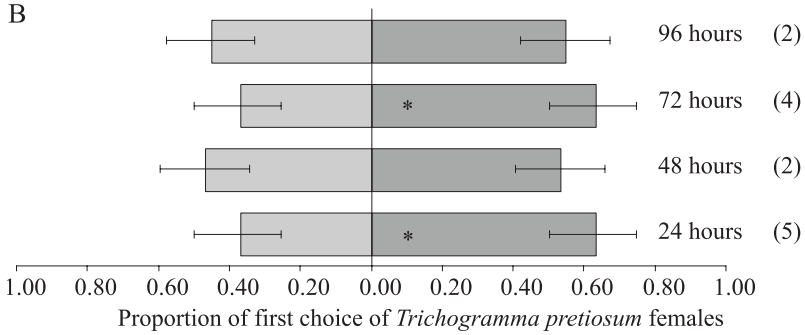

Figure 4. First choice of the egg parasitoid Trichogramma pretiosum in Y-tube olfactometer subjected to the following treatment combinations: A, air vs. undamaged corn plants and manually damaged vs. undamaged corn plants; B, undamaged corn plants vs. Elasmopalpus lignosellus larvae damaged plants. * Significant at $5 \%$ probability by the chi-square test. Lines indicate $95 \%$ confidence interval.

\section{Conclusion}

Volatile organic compounds released by corn plants damaged by Elasmopalpus lignosellus may act as an indirect defense, attracting Trichogramma pretiosum.

\section{References}

CHALFANT, R.B. A simplified technique for rearing the lesser cornstalk borer (Lepidoptera: Phycitidae). Journal of the Georgia Entomological Society, v.10, p.33-37, 1975.

COLAZZA, S.; FUCARINO, A.; PERI, E.; SALERNO, G.; CONTI, E.; BIN, F. Insect oviposition induces volatile emission in herbaceous plants that attracts egg parasitoids. Journal of Experimental Biology, v.207, p.47-53, 2004a.

COLAZZA, S.; MCELFRESH, J.S.; MILLAR, J.G. Identification of volatile synomones, induced by Nezara viridula feeding and oviposition on bean spp., that attract the egg parasitoid Trissolcus basalis. Journal of Chemical Ecology, v.30, p.945-964, 2004b.

D'ALESSANDRO, M.; BRUNNER, V.; VON MÉREY, G.; TURLINGS, T.C.J. Strong attraction of the parasitoid Cotesia marginiventris towards minor volatile compounds of maize. Journal of Chemical Ecology, v.35, p.999-1008, 2009.

D'ALESSANDRO, M.; TURLINGS, T.C.J. Advances and challenges in the identification of volatiles that mediate interactions among plants and arthropods. The Analyst, v.131, p.24-32, 2006.
HEIL, M. Indirect defence via tritrophic interactions. New Phytologist, v.178, p.41-61, 2008.

HEIL, M.; TON, J. Long-distance signalling in plant defence. Trends in Plant Science, v.13, p.264-272, 2008.

HILKER, M.; MEINERS, T. Induction of plant responses towards oviposition and feeding of herbivorous arthropods: a comparison. Entomologia Experimentalis et Applicata, v.104, p.181-192, 2002.

JHAM, G.N.; SILVA,A.A.da; LIMA, E.R.; VIANA, P. Identification (GC and GC-MS) of unsaturated acetates in Elasmopalpus lignosellus and their biological activity (GC-EAD and EAG). Journal of Separation Science, v.28, p.281-285, 2005.

JHAM, G.N.; SILVA, A.A. da; LIMA, E.R.; VIANA, P.A. Identification of acetates in Elasmopalpulus lignosellus pheromone glands using a newly created mass spectral database and Kóvats retention indices. Química Nova, v.30, p.916-919, 2007.

KÖLLNER, T.G.; HELD, M.; LENK, C.; HILTPOLD, I.; TURLINGS, C.J.; GERSHENZON, J.; DEGENHARDT, J. A maize $(E)$-beta-caryophyllene synthase implicated in indirect defense responses against herbivores is not expressed in most American maize varieties. The Plant Cell, v.20, p.482-494, 2008.

LOUGHRIN, J.H.; MANUKIAN, A.; HEATH, R.R.; TURLINGS, T.C.J.; TUMLINSON, J.H. Diurnal cycle of emission of induced volatile terpenoids by herbivore-injured cotton plants. Proceedings of the National Academy of Sciences of the United States of America, v.91, p.11836-11840, 1994.

LYNCH, R.E.; KLUN, J.A.; LEONHARDT, B.A.; SCHWARZ, M.; GARNER, J.W. Female sex pheromone of the lesser cornstalk borer, Elasmopalpus lignosellus (Lepidoptera: Pyralidae). Environmental Entomology, v.13, p.121-126, 1984.

MICHEREFF, M.F.F.; LAUMANN, R.A.; BORGES, M.; MICHEREFF-FILHO, N.; DINIZ, I.R.; FARIAS-NETO, A.L.; MORAES, M.C.B. Volatiles mediating a plant-herbivore-natural-enemy interaction in resistant and susceptible soybean cultivars. Journal of Chemical Ecology, v.37, p.273-285, 2011.

MORAES, M.C.B.; LAUMANN, R.A.; PAREJA, M.; SERENO, F.T.P.S.; MICHEREFF, F.F.; BIRKETT, M.A.; PICKETT, J.A.; BORGES, M. Attraction of the stink bug egg parasitoid Telenomus podisi to defence signals from soybean activated by treatment with cis-jasmone. Entomologia Experimentalis et Applicata, v.131, p.178-188, 2009.

MORAES, M.C.B.; LAUMANN, R.A.; SUJII, E.R.; PIRES, C.; BORGES, M. Induced volatiles in soybean and pigeon pea plants artificially infested with the Neotropical brown stink bug, Euschistus heros, and their effect on the egg parasitoid, Telenomus podisi. Entomologia Experimentalis et Applicata, v.115, p.227-237, 2005 .

MORAES, M.C.B.; PAREJA, M.; LAUMANN, R.A.; HOFFMANN-CAMPO, C.B.; BORGES, M. Response of the parasitoid Telenomus podisi to induced volatiles from soybean damaged by stink bug herbivory and oviposition. Journal of Plant Interactions, v.3, p.111-118, 2008. 
PIRES, C.S.S.; VILELA, E.F.; VIANA, P.A.; FERREIRA, J.T.B. Avaliação no campo do feromônio sexual sintético de Elasmopalpus lignosellus (Lepidoptera: Pyralidae). Anais da Sociedade Entomológica do Brasil, v.21, p.59-68, 1992.

R DEVELOPMENT CORE TEAM. R: a language and environment for statistical computing. Vienna: R Foundation for Statistical Computing, 2010.

STONE, K.J. Reproductive biology of the Lesser Cornstalk Borer. I. Rearing technique. Journal of Economic Entomology, v.61, p.1712-1714, 1968.
VET, L.E.M.; DICKE, M. Ecology of infochemical use by natural enemies in a tritrophic context. Annual Review of Entomology, v.37, p.141-172, 1992.

VIANA, P.A. Lagarta-elasmo. In: SALVADORI, J.R.; ÁVILA, C.J.; SILVA, M.T.B. da (Ed.). Pragas de solo no Brasil. Passo Fundo: Embrapa Trigo, 2004. p.379-408.

WILLIAMS III, L.; RODRIGUEZ-SAONA, C.; CASTLE, S.C.; ZHU, S. EAG-active herbivore-induced plant volatiles modify behavioral responses and host attack by an egg parasitoid. Journal of Chemical Ecology, v.34, p.1190-1201, 2008.

Received on September 24, 2010 and accepted on May 27, 2011 